The main government organization for sponsoring research in Italy is the National Research Council, with an income for 1952-53 of 3 million dollars, while it is estimated that about $2 \cdot 3$ million dollars a year is spent on research in the universities, another $2 \cdot 7$ million dollars by government departments and nearly 250,000 dollars by the learned societies, professional associations and scientific foundations. Estimates are given of the expenditure on industrial research by individual firms-for example, 924,000 dollars each by the Montecatini Co. on chemical research and by the Fiat Co. on mechanical engineering research-but not for industrial research organizations as a whole.

In the Netherlands the Central National Organization for Applied Scientific Research has been responsible since 1932 for the direction of applied research in accordance with national needs and had a budget for 1951 of 3.4 million dollars, of which $2 \cdot 37$ million dollars came from the government and the remainder chiefly from industry. In Norway, where the universities themselves come under the Ministry of Education, most scientific and technical research, apart from that at the Christian Michelsen's Institute, Bergen, and that of the Society for Industrial and Technical Research at the Norwegian Technical College, Bergen, is carried out directly, under the government or with government assistance, which provided about 8 million dollars for research and development during 1952-53. The Royal Norwegian Council for Scientific and Industrial Research is responsible for the furtherance of fundamental research as well as for planning technical research in accordance with the needs of industry. Expenditure on scientific and technical research in $1952-53$ is estimated at about $8 \cdot 2$ million dollars, of which 1.8 million was in universities and technical colleges, $2 \cdot 1$ million in public research institutes, 630,000 in institutes under the Council for Scientific and Industrial Research, and about 2.5 million dollars in industrial laboratories, with a research staff of about nine hundred, of which 290 are in the universities and technical colleges and 182 in public research institutes.

Information on research expenditure in Sweden is much less complete. The Royal Swedish Academy of Science received government grants amounting to 243,000 dollars during 1951-52 for research work at the Nobel Institute for Physics and Chemistry, the Stockholm Observatory and other institutes under its control. The Royal Swedish Academy of Engineering Sciences received a government grant of 25,000 dollars and also support from industry. Of the four State Research Councils, that for Technical Research had a budget for 1951-52 of 212,000 dollars, the Committee for Building Research 67,500 dollars and the Atomic Energy Committee 367,000 dollars. Applied research is carried out to some extent by various government laboratories which have a total budget of nearly $\mathbf{1 \cdot 3}$ million dollars, while the combined budgets of the Forest Products Research Laboratory, the Textile Research Institute, the Metallographic Institute and the Food Preservation Research Institute are $\mathbf{7 7 6 , 0 0 0}$ dollars, of which 235,400 dollars are provided by the State. A survey of thirty-seven of the larger industrial research laboratories indicated that they employed a scientific and technical staff of 340 out of a total of 2,300 , and the total expenditure on industrial research is estimated at about 10 million dollars a year. The interchange of information between research workers and industry is facilitated by the Researchers Contact Organization.

In Switzerland applied rescarch is organized at the national level through the Society for the Promotion of Research at the Federal Technical College, the Commission for the Sponsoring of Scientific Research, the Swiss Research Council for Atomic Energy and the Swiss National Foundation for Scientific Research. No comprehensive data are available for Federal expenditure on research, but 936,000 francs were allocated for scientific research by the Federal Council in 1945, and the Swiss Federal Institute of Technology in 1951 received Federal credits amounting to 2 million dollars, the Swiss National Foundation for Scientific Research was to receive Federal grants increasing to 936,000 dollars in its third year, while some 3.25 million dollars were expended in 1951 on research and development by the Division of War Technology of the Federal Military Department. It is estimated that the firms of Ciba and Sandoz spend about 5.85 million dollars a year on research, and Brown Boveri about the same amount. The Aluminium Foundation was established by the Aluminium Industrie A.G. of Nordhausen to support promising investigations in applied chemistry, particularly electrochemistry and electrometallurgy, and a number of other Swiss firms and industrialists have established foundations for scientific research in medicine, biology, etc.

\section{BRITISH INDUSTRY AND SCIENTIFIC MAN-POWER}

$T$

HE first part of the address of Sir Harry Pilking. ton, president of the Federation of British Industries, to the annual meeting at Reading, on September 21, of members of the Southern Region of the Federation, stressed the importance of the export trade to the British economy and indicated that we are on the eve of another big effort by the Federation in this field, the Trade Fair at Baghdad. He said that we are the people in the whole world whose future, safety and survival most depends on the growth of international trade, and on the credit side that means the export of manufactured industrial products. We must constantly improve our productivity, attempt to increase our share of world trade, but still more expand the total of world trade and develop the purchasing power of growing markets overseas, including the raising of the standard of living of those people whose standards are far below our own.

Sir Harry said that the new industrial revolution under way completely overshadows that of the nineteenth century, and means a demand for more, and more highly qualified, scientists. The Federation's Education Committee is concerned here both with recruitment and training, including the shortage of science teachers. We shall not obtain the rise in productivity we require, he thinks, unless we have more people with a good scientific background-not merely more outstanding inventors, but more people competent to carry out the ordinary analytical work and team-work of development. Sir Harry then emphasized the high cost of invention to-day. This is now the result of team-work and leadership, and often involves enormous sums before inventions are developed to a commercial stage. $\mathrm{He}$ does not believe that Britain or any other country can afford 
to allow all its best scientists to work in isolated compartments on the same problem, without access at least to other people's mistakes. Broad views of the advantages of pooling resources of inventiveness, or of pooling results, are of the utmost importance to Britain and to mankind as a whole. He therefore urged industrial firms to re-assess the work of their research departments, and where research institutes or associations for the whole of the industry do not exist, to try to devise other means for pooling with their neighbours or their competitors results of their development work.

Sir Harry remarked that some of our man-power resources are still being used wastefully, and touching on the question of taxation said that to abolish de-rating would give a great shock to industrial confidence in Britain and undo all the good resulting from the encouragement given last April to investment in plant and machinery. He urged member essociations and individual firms to make their own cases showing what would be the effect, industry by industry, of a re-introduction of full rating on top of revised valuations.

Although Sir Harry complained of the high level of employment in the Civil Service, he welcomed the endorsement by the Government and the Civil Service as a whole of the findings of Sir John Wood's Committee in the Crichel Down case, and said that it is equally important that private citizens, and especially industry, should show like consideration to Civil servants.

\section{BRITISH PHARMACEUTICAL CONFERENCE, 1954}

$\mathrm{T}$

HE ninety-first British Pharmaceutical Conference was opened at Oxford on September 13 and nearly five hundred members attended.

Dr. H. Davis, in his chairman's address, discussed the impact of National Health Service on pharmacy and outlined how the changing pattern of prescribing and dispensing demands from the pharmacist of to-day less manipulative skill but a more detailed scientific knowledge of drugs and processes than was formerly required. This changing demand is reflected. in the research papers read at the Conference.

Two of the papers are of general interest. The first, on demineralized water, shows that with correct technique demineralization of tap water by mixed anion and cation exchange resins produces a water of purity at least equal to that of distilled water B.P. The second general paper was a discussion of entrainment of liquid in distillation. It was shown that when the flow of vapour in the still-head was in streamline flow, the amount of entrainment increased with diameter of still-head and was proportional to Reynolds number.

Research of specific interest to practising pharmacists included a study of the $p H$ of the castor oil soap in the preparation of a solution of chloroxylenol in an attempt to obtain a constant product. The increased use of newer emulsifying agents is reflected in the report on polyethylene-glycol esters of cetostearyl alcohol, in which it was shown that when used alone the lower members of the series (two or four ethylene oxide units) are more effective in emulsifying arachis oil. Also in the emulsion field, an interesting point was that the addition of bentonite to certain cream bases will permit them to be autoclaved without creaming or separation of the oil.

Stability of preparations of drugs is always an important subject in pharmaceutical analysis. A quick iodometric method for estimating the hydrolysis of succinylcholine chloride, confirmed by chromatographic and biological assays, has shown that increased temperature $\left(20^{\circ} \rightarrow 37^{\circ}\right.$ C. $)$ greatly increases the instability of this drug. Since ferrous iron is more readily adsorbed than ferric iron, oxidation of ferrous gluconate solutions should be prevented; it has been found, by suitable formula. tion and storage in light, that the ferrous iron content of such a solution may increase slightly, but this is accompanied by some deposition from the solution. The most stable solution is a 10 per cent solution stored in small, completely filled containers, stabilized with $7 \cdot 5$ per cent dextrose monohydrate and stored protected from light.

It is interesting to find that the sugar coating of tablets of penicillin intended for oral use not only masks the bitter flavour but also protects the contained penicillin from external moisture, and so increases the stability that they can then be stored for two years at $25^{\circ} \mathrm{C}$.

The instability of tincture of digitalis has been a puzzle, since the frog lymph sac method of assay showed loss of potency on storage whereas the cat intravenous method did not. Fresh light has been thrown on this subject by two workers who, using a frog intravenous method, have shown that this method also indicates a drop in activity on storage and so the disagreement between the two methods of assay is not due to differences in absorption. They suggest that on storage the primary glycosides in the tincture are hydrolysed to secondary glycosides but not down to the genins.

The correlation shown between three methods of measuring pyrogenic activity-temperature rise, fall in percentage of small lymphocytes and fall in average number of lobes per neutrophil-will give pharmacologists a double confirmation of the results of pyrogen tests.

A very neat method of studying the pereutaneous absorption of substances from ointment bases has been devised. Injection of acetylcholine into a rat causes secretion of reddish-brown tears; this effect is increased by eserine, and the response can bo used for an assay of the eserine. By incorporating the eserine in an ointment base and rubbing on the skin of the rat, the amount absorbed can be ascertained.

A number of papers on the analytical aspect of research were presented, including biological and chemical assays.

In a new type of apparatus it has been shown that the rate of disinfection of solids by formaldehyde vapour is dependent on the amount of vapour per. meating the solid rather than the concentration of formaldehyde in the vapour.

The adsorption of phenol on activated charcoal, or on a precipitate caused when ferric chloride was added to the bacteriological medium used for detecting survivors from a phenol-Bact. coli mixture, showed no apparent effect on the survival-rate.

An infusion of raspberry leaves has a traditional use in giving easy and speedy parturition. Preliminary investigation into the active principles which may be responsible for this effect have led to the separation of three fractions, one a spasmolytic factor which may antagonize the stimulant effect of the other two factors, and might explain the negative 